\title{
Climate Change, Ecological Risk in Mumbai and Kolkata with reference to Amitav Ghosh's The Great Derangement: Climate Change and the Unthinkable -An Ecocritical Review
}

\author{
Seema S. R
}

Research Scholar, Kuvempu University, Shimoga, Karnataka, India.

Received: 20 Sept 2020; Received in revised form: 15 Nov 2020; Accepted: 23 Nov 2020; Available online: 07 Dec 2020 (C)2020 The Author(s). Published by Infogain Publication. This is an open access article under the CC BY license (https://creativecommons.org/licenses/by/4.0/).

\begin{abstract}
Climate change has reversed the temporal order of modernity: those on the margins are now the first to experience the future that awaits all of us ...", Amitav Ghosh on Tidal surges in his The Great Derangement: Climate Change and the Unthinkable(2016).

Till the end of the early modern period, human habitats were traced by the side of river banks, not by the side of the seashore. The latter was regarded with awe, due to its unpredictable storms. Although people inhabited the coastal regions, chose a safe and remote place eventually. In contrast to this pragmatism, colonial rule has cherished a manipulative anthropogenic attitude, by settling along the seashore. This shift in the habitat has directly exposed the people's lives to risk. In this context, the present two coastal megacities: Kolkata and Bombay have a historical legacy of inundating the population into havoc. But, what could be the reasons for increased storm surges and deluge in the recent past? Indeed, the politics of development has accelerated the pace of disaster on both; dwellers and eco-sensitive biosphere. The mangrove ecosystem protecting these coastal areas is a habitat for biologically diverse flora and fauna, which are threatened by habitat degradation. This paper analyses the triggered risk factor for the lives of people and the species in those coastal megacities, due to unabated, often unchallenged developmental projects and climate change, from an ecocritical perspective. To exemplify this argument Amitav Ghosh's The Great Derangement: Climate Change and the Unthinkable is referred in this paper.
\end{abstract}

Keywords - climate change, coastal megacities, Kolkata, Bombay, risk, ecocritical, Amitav Ghosh.

\section{INTRODUCTION}

Every Indian has witnessed the recent cyclone Amphan and Nisarga befalling on the coastal megacities, Kolkata and Mumbai in May and June 2020 respectively. The monsoon in the following months has deluged a few districts and villages very pitifully, in some regions people were victim to the landslides. Just a few months before these onslaughts, there was a breakdown of the pandemicCOVID 19, across the world. Depending on the severity of the situation, governments ordered lock-down for the safety of the residents. However, one rejuvenating fact of the lock-down was that, nature got self-healed, without human beings intervention; pollution drastically reduced, creatures and mountains which were kept under the garb of pollution for many decades, have made their appearance and water beds cleaned themselves. Is there any connection among these uncanny events; simultaneous (deadly) cyclones on either side (never heard) of the Indian Ocean, flood in most parts of India, and the Pandemic? Aldo Leopold, an icon in conservation in his book, A Sand County Almanac (1949), warns,

The effort to control the health of land has not been very successful. It is ...understood that when soil loses fertility or washes away faster than it forms, and when water systems exhibit abnormal floods and shortages, the land is sick. 
The disappearance of plants and animal species without visible cause, despite efforts to protect them, and the irruption of others as pests despite efforts to control them,... simpler explanations, be regarded as symptoms of sickness in the land organism. (166)

In this vein the paper attempts to analyze two coastal megacities, Mumbai and Kolkata ecocritically for their frequent deluge, either by flood or storms, and the intensified risk factor in those regions. The paper constraints its examination to the mentioned cities due to their colonial as well as the present ecological riskintensified topographical connection (though Chennai is one among the coastal megacities in India, was the first colonial port city and facing the same risk). Thanks to the meteorological department, except for property loss, many lives are saved compared to the devastation thronged decades before. But, the downpour in July and August has inundated many districts in India, along with coastal megacities. These uncanny, unprecedented deluge or storms are becoming normal for a few years, due to frequent encounters. The climatic change has transformed millions of people's lives into vulnerable.

\section{ECOCRITICAL METHOD}

Climatic change has a scientific deliberation, experienced through global warming, bizarre tropical cyclones, and rain. However, does climate change has anything to do with human behavior or attitude or culture? Indeed, ecocritics find the entwined connection between the two and believe that anthropogenic intervention is the root of all the climatic mayhem. Ecology is no longer restricted, confined to the discipline of science in this symbiotic world, where, we can find complex enmeshment of diverse factors affecting the ecosystem. An ecocritical perspective is a multidisciplinary approach to analyze this human intervention on the ecological crisis. Ecocritics strongly feel that ecological risk (induced by climate change) is the manifestation of the crisis of culture. Amitav Ghosh in his non-fiction, The Great Derangement (2016) observes that the Anthropocene presents a challenge to contemporary culture in general (12). In this context, the paper proposes to study the oppressive objectifying culture of humans, which is dooming the ecosystem of the two coastal megacities; Mumbai and Kolkata.

People loved to live by the side of the water, though they feared to settle with huge mansions near the coastlines. Sea or Ocean waters were feared for its unprecedented hazards. Simon C Estok finds this fear of the natural world as 'ecophobia', in his book Ecocriticism and Shakespeare Reading Ecophobia (2011), portrayed in William Shakespeare's drama King Lear, where the king turns out to be a feeble and victimized before the weather, unhoused and alienated (6). This ecophobia across the world, during the pre-colonial history, locates old coastal cities: Surath, Kochin, London, Stockholm, Lisbon, and many others, away from the open seas, oceans, estuaries, or deltaic systems. Albeit, the enlightenment era in the western culture has empowered man to the zenith of superiority, and control both living and nonliving things. Another play by Shakespeare The Tempest is a metaphor for imperials power over the colonies and nature, Prospero's creation of tempest is the manifestation of man's "divine authority to control everything" (Estok 5). Contrary to the pragmatic urban plan of old coastal cities, the new colonial port cities Madras, Bombay, New York, Hong Kong, and Kolkata exemplify anthropocentric attitudes in their inception. Renaissance intellectuals found these emerging cities as a platform to implement their urban planning. The financial flow to these port cities strengthened political power, to fetch more merchants and workers and hierarchy, and to invest in structuring the cities. Caitlin Vandertop in her article, "Opium, cities, carbon routes: World-ecological prehistory in Amitav Ghosh's Hong Kong" notices that the short term logic of colonial development and the imperative of coastal urbanization has resulted in the contemporary displacement of millions of people to dangerously exposed locations (530). With the economic and political establishment, East India Company gradually erected churches, hospitals in those cities, however, had reserved the governor's mansions - peculiarly significant- to the proximity of the sea's landscape. The location brought a powerful ethos and authoritative symbol of a victory. The postcolonial settlers blindly followed this legacy of 'status symbol' culture and thus had put their lives into jeopardy. After the colonial period, people from neighboring states flooded to these cities, in search of economic prosperity, thus metamorphosed the cities into (before the legal declaration) megacities (Ten million population is the criteria to be declared as megacities). According to the 2020 survey, the approximate demography in Mumbai is 20 million and Kolkata- 14.8 million ("India"). Indeed this population pressure will have a massive impact on the coastal land and thereby menacing the surrounding ecosystem. Aldo Leopold observes, "one of the fastest shrinking categories ... is coastline" (Leopold 162).

\section{Mumbai}

Mumbai a coastal megacity lures everyone irrespective of age with its enchanting geographical, 
commercial, cultural, and entertaining industry. People do migrate to Mumbai from across India to build their life, without the awareness of risk awaiting for them. Risk, in the form of a deluge, man-made disaster, is crushing everybody's dream. This dream city's history starts with the colonial era in India, with its trading activity since the 1670 s, to grow into the largest port in the western part of India.

Before the colonial era, Mumbai was an archipelago of seven islands, having a natural harbor. British in competition to the old Surath port developed colonial Bombay by reclaiming the land in between the islets in the seventeenth century. British cajoled many Parsi merchants from Gujarath to establish their entrepreneurial business and laborers to settle in Bombay. The opportunity arrived in the form of cotton export to European nations during the American civil war in the 1860s. The growing opium trade with China along with the cotton business had transformed Bombay into a commercial junction in the capitalist world economy and rose to become "the locus of major cotton textile industry that was founded and dominated by Indian entrepreneurship" (Patel 4). The city gradually attracted a huge flow of population. After independence, Mumbai grew unchallenged on the accepted norms of the colonialists. Currently, the second largest Municipality in the world, having a 20 million population, Mumbai is sprawling vertically to the landscape of the shore by encroaching and reclaiming the land of the coast. The centuries-old drainage system, industrial discharge to the water, and the rocket pace urbanization have put the city into the cauldron.

British called Bombay, Urbs Prima in Indis and addressed as "the Manchester of the East". Bombay, which lies on the west coast of the Indian Ocean, does not have a history of frequent cyclones and seismic sea waves like the east coast. However, records unravel the terrific encounter of strong storms on Bombay in 1618, 1740, 1783, and 1854 causing the loss of many lives and property (Ghosh Amitav 57-58). Later, there were no major calamities reported until the end of the twentieth century. Three cyclones hitting the city between 1998 and 2001 is a testimony to the changing climate. " ... cyclonic activity in the Arabian Sea is also likely to intensify because of the cloud of dust and pollution that now hangs over the Indian subcontinent to changes in the region's wind patterns" (Ghosh Amitav 55). Despite the devastating rainfall (record braking rainfall in one day in any city) of 2005, and 2015s flood, poor political will, and urban planning continue unabatingly, without the heed to retain the natural defenders like mangrove forest, wetland and salt pan. For instance: a coastal road project along the Arabian Sea to link the two ends of Mumbai without the environmental clearance and permission to a hotel on 'no development zone' in 2019. But, their progress is on hold due to the intervention of the High court. The Arabian Sea is cooler compared to the Bay of Bengal, hence, the coast is exposed to less cyclonic frequency. Although, the changing life culture - eco-insensitive urban planning, pollution - is heating the atmosphere. In 2015, records manifested the Arabian Sea engendering more storms than the Bay of Bengal (Ghosh Amitav 58), and five storms formation in 2019 (Sen and Vineetha). And the storms, on both sides of the Indian Ocean, were a very strange and unnatural event in history. The same strange event got repeated and thrashed on both the mega-cities with a few weeks difference in the year 2020; Cyclone Amphan and Nisarga. According to the scientific prediction these kinds of exceptional calamities will be normal in prospective years. The more chilling fact is the location of two nuclear facilities: the Bhabha Atomic Research Centre at Trombay (14 Km from Mumbai), and Tarapur Atomic Power Station (94 km from the periphery). Rising sea levels and floods are of great risk by damaging the safety measures. If liquid radioactive waste gets mixed with the water, the whole area will be in danger of contamination (Ghosh Amitav 69-70).

Besides this temperature rise and storm surge, the geologists have recently discovered Amitav Ghosh points "previously unknown and probably very active fault" (54) in the Arabian Sea, $800 \mathrm{~km}$ long facing the west coast of India. "These results will motivate a reappraisal of the seismic and tsunami hazard assessment in the NW Indian Ocean" (ibid). If a tsunami hits, tides would not look for the disparity between privileged or marginalized, it levels everyone equally. Those who think safe in the skyscrapers (near the shore) are the first to be affected. Meanwhile, COVID 19-Corona virus, a great equalizer has provided a relaxing air to the city, which never sleeps.

\section{Kolkata}

Kolkata is the epicenter of manufacturing industries, commerce, service, trade and plays a vital role as a port city. Kolkata, the capital city of the West Bengal state, is "the Cultural Capital" of India, located $180 \mathrm{~km}$ away from the Bay of Bengal and the second coastal megacity, having a population of 14.8 million. During the colonial era, it was the last port city to be found in India by the British in the late seventeenth century. Without the political rivalry like Mumbai and Chennai, the imperials established their sovereignty over the fertile Bengal Province, creating Kolkata as their capital. As the place was near the Bay of Bengal, the British considered only 
trade, sea route transportation, business, and profit. They did not heed the warnings of the topography, forthcoming vulnerability on the city, and its residents. The development of the colonial cities in India had acknowledged the confidentiality of the selfish motto. The Opium trade had strengthened the capital politically, economically, and socially. Kolkata, a commercial capital is on the banks of the river Hoogly, is situated on the Gangetic delta. A typical riverine city was constructed by clearing the surrounding marshes, tidal creeks, mangroves, swamps, and wetlands (Ghosh, Asish 1). Despite the efforts, the river gradually started silting. Hence, a new site near the Bay of Bengal, -banks of the river Matla was chosen. The same methods were adopted on the banks of Matla (against the warning of a cyclone, by Henry Piddington) and port Canning was inaugurated in 1864, with all the luxuries containing a railway station, banks, and hotels. However, within three years, the city was shattered by a moderate cyclone, and the British abandoned the city (Amitav, Ghosh 77). Both the rivers are estuaries of the Gangetic delta, what port Canning had witnessed then, Kolkata has started getting affected gradually, facing dreadful cyclones as the city grew on the model of the colonial foundation. Unheeding to the climatic danger, the port city was developed as the commercial capital to the British on the banks of Hoogly. After India's independence, nature exploiting urban growth continued with diverse, hazardous factories, structures, pressurizing, and polluting the river along with the migrated working population.

Kolkata, the city of the swamp, though $180 \mathrm{~km}$ away from the coastal line, is a victim to the direct encounter of the cyclones, because of deltaic settings, below the sea level existence and strong storms. The rapid destruction of wetland and urbanization has increased the frequency of cyclones beyond four times in recent decades - 93 depressions occurred on the Bay of Bengal between 1891-1930, and 371 between 1931-1970(Gosh, Asish 4).

The Bay of Bengal is the largest bay in the world, and a site of the majority of deadliest tropical cyclones in world history (Biswas), and 74\% of deadliest cyclones have been documented in the sea. Their frequency is five times more than the Arabian Sea. The cause for these worst storm surges is, "semi-enclosed nature of this basin in conjunction with its funnel shape steers cyclone pathway striking the land" (Sahoo and Prasad). What makes it still worse and a strong storm is the sea surface's warm temperature. Bob Henson, meteorologist, and writer with Weather Underground, points that the north coast of the Bay of Bengal is more prone to catastrophic surges than anywhere on Earth (Biswas). Meteorologists recall that though one cyclone in every ten years might be formed as a super cyclone, however, there is a rise in the frequency of intense cyclones in the Bay in the last few decades. Indeed the credit goes to human-induced hydrologic temperature rise in the atmosphere. Despite the precautionary measures for the cyclone Amphan in West Bengal, the report documents 98 human lives and damage of Rs. 1 lakh crore worth of property (Sen and Vineetha). Some parts of Kolkata received record high rain $-200 \mathrm{~mm}$ in twenty-four hours. Tropical Meteorologists opined that along with the intensity of the cyclone the warmer climatic condition played a spoiling game on the city. Besides, the cyclone has damaged one-third of mangroves in the Sundarbans, a natural defense (Ghosh S), which is recognized as Ramsar Site in 2019.

The Intergovernmental Panel of Climate Change's Fifth Assessment report states that by the 2070s, both Mumbai and Kolkata are at high risk as population and assets are exposed to the coastal deluge. Millions of residents are exposed to one or multiple hazards with floods and cyclones (Ghosh S). Are these bizarre climatic conditions communicating the approaching risk on everybody and everything? If we do not act accordingly at least now, the future will be filled with catastrophes. Precautionary measures, rehabilitation to millions is humanly impossible. We need to develop a value system to live on our needs but not on wants. These cyclones and frequent floods are communicating human beings, the need to give attention to nature.

\section{Eroding natural defense and species}

The coastal ecosphere is a unique and vital habitat for varied species, compared to terrestrial, as they harbor the transitional geography between sea and land, having the effect of and on both. An estuary, where river water merges with tides, forms a rich natural resource and source of natural gas or oil. Hence coastal zones have wide significance to all, human - marine food, commercial importance, socio-cultural and transportation; animals, plants, the atmosphere, and the climate. Mangroves are natural shock absorbers of floods and storms to protect the hinterland. Mangroves are the massive storehouse of carbon in the atmosphere, hence vital to mitigate the effect of climate change.

The grey mangrove or Avicennia marina is the mangrove species widely found in the Mumbai region. The reduction of mangrove to 42 square $\mathrm{km}$ along the Mithi river had resulted in the flood of 2005. Mumbai Mangrove Conservation Unit (established after 2005), is the only unit in India to protect and conserve the mangrove of the region and has increased to 66 square $\mathrm{km}$ by artificially growing, 
till 2017 (Chandramouli). However, dumping urban debris chokes the plants to death, political and social pressure in encroaching the mangrove continues. The environment activist Debi Goenka predicts the biggest threat to the mangrove from the Government projects and fears "since climate change is not part of any decision-making process yet, the city might end up back in original form, as seven independent islands" (Chandramouli). 21 hectares of saltpan (which buffers deluge) have been streamlined for the construction. Apart from all these, rivers' -Mithi, Dahisar, Poisar, Oshiwara- wetlands have proved to be fortunate to Mumbai's landscape in protecting the city (Srivastava and Aditi). But alas, even they are choked with domestic and industrial waste.

The Bay of Bengal coast has the largest delta formed by the mighty rivers Ganges, Brahmaputra, and Meghana. The delta has formed a unique archipelago of thousands of islands, which are collectively protected by Sundari mangrove trees called Sundarbans- one of the largest mangrove forest in the world (Both W Bengal and Bangladesh). Since the British colonial era, Sundarbans were cleared and drained for cultivation or extension of the city. In 1975, the then Indian government has cleared some acres of Sundarbans for revenue-generating plantation (Anand 31). In 2000 Sahara Business Group in association with the state government had come out with the plan to convert part of Sundarbans into ecotourism projects. To protect the unique biodiversity and to maintain the tranquility, the central government - on heeding to the opposition from environmentalists - intervened and ceded the project. Kolkata, which is also known as the city of swamps, due to human beings' intervention and climate change has put its dwellings at extreme risk. The main sewage is discharged to the east Bengal wetlands, lack of cleaning is taking a toll on 12,000 hectares of the mangroves (Ghosh Asish 5). Kolkata, a manufacturing hub, where industries and factories are located on either side of the rivers are polluting and channelizing the same to the wetlands. Sundarbans spread across both the nations (India and Bangladesh) has been recognized as "World Heritage Centre" by UNESCO for its unique ecosystem. Royal Bengal Tigers are the beauty of the Sundarbans. The loss of habitat has put them in danger. Based on the ratio of fresh and saline water, there are wide verities of aquatic species in the Sundarbans eco-space; from tiny fish to predatory estuarine crocodiles. Among them is the rare freshwater Gangetic river dolphins -Platanista gangetica, found in the estuaries and Irrawaddy dolphins -both fresh and saltwater. But the reduced fresh water and increase in salinity have dwindled the number of Gangetic dolphins. Climate change, rise in the temperature of water and river traffic, underwater sounds of the boats affect the behavior of the dolphins, sometimes to the extent of stranding or beaching.

\section{CONCLUSION}

The ecological mayhem of the two coastal megacities discussed in this paper intensifies the need to save our surroundings, not for the prospective generation but for the survival of the current population. Amitav Ghosh in one of his interviews mentions, "that we have lost a sense of connection with our surroundings. Human centeredness ... blind us to the consequences ..." (Ghosh Amitav, Interview). Climatic crisis is the consequence of western centred model of anthropocentric culture in all kinds of developmental projects. However, the encountering natural calamities and their risks on the ecosystem are warning every human being to come together to save at least their surrounding ecosystem.

\section{ACKNOWLEDGMENT}

The author declares that the submitted paper is original work, not published anywhere either in print or online blogs, and on reproducing sources, proper acknowledgment has been done in the paper.

\section{REFERENCES}

[1] Anand, Divya. "Words on Water: Nature and Agency in Amitav Ghosh's The Hungry Tide." Concentric: Literary and Cultural Studies, vol. 34, no. 1, 2008, pp. 21-44. www.concentric-literature.url.tw/issues/Water/2.pdf. Accessed 13 June 2020.

[2] Biswas, Soutik. "Amphan: Why Bay of Bengal is the world's hotbed of tropical cyclones." $B B C$ News, 19 May 2020, www.bbc.com/news/world-asia-india-52718531. Accessed 17 August 2020.

[3] Chandramouli, Kartik. "She guards Mumbai's defense against climate change." Mongabay, 25 July 2019. https://india.mongabay.com/2019/07/she-guards-mumbaisdefence-against-climate-change/. Accessed 28 July 2020.

[4] Estok, Simon C. Ecocriticism and Shakespeare: Reading Ecophobia. 1st ed, Palgrave Macmillan, 2011.

[5] Ghosh, Amitav. The Great Derangement: Climate Change and the Unthinkable. Penguin Books, 2016.

[6] ..., Interview. "Asian Perspectives on Climate Change." Web. amitavghosh.com

[7] Ghosh, Asish. Kolkata and Climate Change. Climate Change Policy Paper IV, WWF4:1-20. 2015, awsassets.wwfindia.org/downloads/kolkata_and_climate_c hange.pdf. Accessed 7 Aug 2020.

[8] Ghosh, Sahana. "Gangetic river dolphins in the Indian Sundarbans struggle with swelling salinity." Mongabay, 17 
Jan 2019, india.mongabay.com/2019/01/gangetic-dolphinsin-the-indian-sundarbans-struggle-with-swelling-salinity/. Accessed 01 Aug 2020.

[9] Ghosh, Sahana. "Lessons from cyclones Amphan and Nisarga for India's disaster management plan.” Scroll.in.05 June 2020, scroll.in/article/963805. Acessed 15 Aug 2020.

[10] "India Population 2020." Web. 09 Sep 2020. https://indiapopulation2020. Accessed 15 Aug 2020.

[11] Kosambi, Meera, and John E. Brush. "Three Colonial Port Cities in India." Geographical Review, vol.78, no. 1, 1998, pp. 32-47. DOI: 10.2307/214304. Accessed 27 July 2020.

[12] Leopold, Aldo. A Sand County Almanac: And Sketches Here and There. Oxford UP. 1949.

[13] Patel, Sujata. "Colonial Port Cities: Mumbai and Chennai." Module 34-8.2, Paper 07, ePG Pathshala. http://epgp.inflibnet.ac.in/epgpdata/pdf. Accessed 12 Aug 2020.

[14] Sahoo, Bishnupriya, and Prasad K. Bhaskaran. "Assessment on historical cyclone tracks in the Bay of Bengal, east coast of India." RMetS. Vol.36, no.1, 2016, pp. 95-109. DOI.10.1002/joc.4331. Accessed 17 Aug 2020.

[15] Sen, Gargi, and Vineetha Nalla. "What Lessons Can India's West Coast Learn From the Cyclone-Weathered East?" Science the Wire, 04 June 2020. science.thewire.in/environment/cyclone-nisarga-mumbaimaharashtra-lessons-east-coast-preparedness-bay-ofbengal/.Accessed 15 Aug 2020.

[16] Srivastava, Kanchan, and Aditi Tandon. " Another monsoon, another deluge: Why Mumbai gets inundated nearly every year." Scroll.in. 10 July 2019. Accessed 27 July 2020.

[17] Vandertop, Caitlin. "Opium cities, carbon routes: Worldecological prehistory in Amitav Ghosh's Hong Kong." Journal of Postcolonial Writing. Vol.55, no.4, 2019, pp. 527-540. DOI. 10.1080/17449855.2018.1562491. Accessed 13 July 2020

[18] Von Glasow, R., Jickells T.D, Baklanov A et al. "Megacities and large urban agglomerations in the coastal zone: interactions between atmosphere, land, and marine ecosystems." AMBIO. Vol. 42, 2013, pp. 13-28. DOI. 10.1007/s13280-012-0343-9. Accessed 29 July 2020. 